\title{
Impact of the Covid-19 Pandemic to the Tourism Industry: Evidence from Vietnam
}

\author{
VAN HONG THI HA ${ }^{1}$, NGUYEN BANG NONG ${ }^{2}$ \\ ${ }^{1}$ Center for Analysis and Forecast, VIETNAM ACADEMY OF SOCIAL SCIENCES, VIETNAM. \\ E-mail: vanhongha@gmail.com. ORCID ID: 0000-0003-1880-8254 \\ ${ }^{2}$ Institute of Anthropology, VIETNAM ACADEMY OF SOCIAL SCIENCES, VIETNAM. \\ E-mail: nguyennb.ioa@vass.gov.vn. ORCID ID: 0000-0001-8196-3543
}

\begin{abstract}
The COVID-19 pandemic appeared in Vietnam from the beginning of 2020. Even during the pandemic, the Vietnamese Government had the policy to encourage domestic tourism, minimizing the reception of foreign tourists. The COVID-19 pandemic has had a significant impact on the tourism industry in Vietnam, particularly in transportation, hotels, and restaurants. From contributing more than US\$32.5 billion in 2019, the tourism industry contributed only US\$13.5 billion in 2020 , down $41.53 \%$. The research paper presents the impact of the COVID-19 pandemic on the tourism industry in Vietnam in 2020. The results show that the tourism industry has suffered the most damage in the history of Vietnam's tourism due to the Covid-19 pandemic. The transportation industry, in which air transport is heavily influenced by international passengers using Vietnam's air, accounts for nearly $80 \%$ of damaged. The research shows that many tourism enterprises are on the verge of bankruptcy. This study also shows that, while private tourism enterprises have not received much support from the state, state enterprises prioritise the Government's support package. The conclusion of the paper shows that tourism enterprises have profit only if they restructure business activities. Furthermore, the tourism industry only survives by connecting airlines, travel agencies, restaurants, hotels, and destinations into one block to create safe destinations, avoid crowded contacts, close range, short-term trips, and ensure domestic tourists' health and safety.
\end{abstract}

Keywords: COVID-19 pandemic; Tourism industry; Tourism enterprises; Vietnam.

JEL Classification: M21, O53, Z30

Received: June 08, 2021

Accepted: November 23, 2021 


\title{
Impacto de la Pandemia de COVID-19 en la Industria del Turismo: Evidencia de Vietnam
}

\author{
VAN HONG THI HA ${ }^{1}$, NGUYEN BANG NONG ${ }^{2}$ \\ ${ }^{1}$ Center for Analysis and Forecast, VIETNAM ACADEMY OF SOCIAL SCIENCES, VIETNAM. \\ E-mail: vanhongha@gmail.com. ORCID ID: 0000-0003-1880-8254 \\ ${ }^{2}$ Institute of Anthropology, VIETNAM ACADEMY OF SOCIAL SCIENCES, VIETNAM. \\ E-mail:nguyennb.ioa@vass.gov.vn. ORCID ID: 0000-0001-8196-3543
}

\begin{abstract}
RESUMEN
La pandemia COVID-19 apareció en Vietnam desde principios de 2020. Incluso durante la pandemia, el Gobierno vietnamita tuvo la política de incentivar el turismo interno, minimizando la recepción de turistas extranjeros. La pandemia de COVID-19 ha tenido un impacto significativo en la industria del turismo en Vietnam, particularmente en el transporte, hoteles y restaurantes. De contribuir con más de US $\$ 32.5$ mil millones en 2019 , la industria del turismo contribuyó solo con US $\$ 13.5$ mil millones en 2020 , un $41.53 \%$ menos. El artículo de investigación presenta el impacto de la pandemia de COVID-19 en la industria del turismo en Vietnam en 2020. Los resultados muestran que la industria del turismo ha sufrido el mayor daño en la historia del turismo de Vietnam debido a la pandemia de Covid-19. La industria del transporte, en la que el transporte aéreo está fuertemente influenciado por los pasajeros internacionales que utilizan el aire de Vietnam, representa casi el $80 \%$ de los daños. La investigación muestra que muchas empresas turísticas están al borde de la quiebra. Este estudio también muestra que, si bien las empresas turísticas privadas no han recibido mucho apoyo del Estado, las empresas estatales dan prioridad al paquete de apoyo del Gobierno. La conclusión del documento muestra que las empresas turísticas solo obtienen beneficios si reestructuran las actividades comerciales. Además, la industria del turismo solo sobrevive al conectarse entre aerolíneas, agencias de viajes, restaurantes, hoteles y destinos para crear destinos seguros, garantizar la salud y seguridad de los turistas nacionales, evitar el contacto masivo, los viajes de corta distancia y de corta duración.
\end{abstract}

Palabras clave: Pandemia de COVID-19; Industria del turismo; Empresas turísticas; Vietnam.

Clasificación JEL: M21, O53, Z30

Recibido: 08 de Junio de 2021

Aceptado: 23 de Noviembre de 2021 


\section{Introduction and literature review}

The tourism industry is a sustainable economic sector (Cooper et al., 2019). However, tourism is also sensitive to crises and natural disasters (Biggs, Hall \& Stoeckl, 2012). For example, the COVID-19 pandemic is an epidemic crisis that directly impacts the tourism industry worldwide (Dube, Nhamo \& Chikodzi, 2021). The COVID-19 pandemic that first appeared in December 2019 in Wuhan, China, has affected more than $90 \%$ of the world's population and directly affected tourism businesses, restaurants, hotels, and airlines (Gössling, Scott \& Hall, 2021.)

In Southeast Asia, where tourism development has been solid for many years, the COVID-19 pandemic had cost Thailand more than US\$47.7 billion in 2020 (Gopalakrishnan, Peters \& Vanzetti, 2020). In Malaysia, the COVID-19 pandemic caused 40\% of tourism industry workers to be affected (Foo et al., 2020). For many years, Thailand and Malaysia have been two of the top 20 most visited countries globally (Yucel, 2020). In Cambodia, the Asia Foundation's survey showed that $72 \%$ of travel agents had no revenue in May-June 2020 (2020). Therefore, it can be said that the COVID-19 pandemic has substantially impacted countries worldwide, including ASEAN countries (Beh \& Lin, 2021).

Tourism was an important economic sector to Vietnam when the sector contributed to the country from US\$5.16 billion in 2010 to US\$32.5 billion in 2019. In 2019, Vietnam's tourism contributed 9.2\% to GDP (Vietnam National Administration of Tourism, 2020). Furthermore, Vietnam's tourism developed strongly with many tourist attractions when Vietnam is home to eight UNESCO World Heritage sites, such as Ha Long Bay in Quang Ninh province (Word Bank, 2019).

The COVID-19 pandemic that appeared in Vietnam from the beginning of 2020 has substantially impacted the tourism industry. The article aims to explore the impact of the COVID-19 pandemic on the tourism industry in 2020. In the article, the authors will answer the question: Which of the following sectors in industrial tourism are affected by the COVID-19 pandemic, such as leading businesses regarding airlines, hotels, and restaurants? The article also mentions the most important policy of the Vietnamese Government for the tourism industry in response to the COVID-19 pandemic.

\section{Methodology}

The study uses data from the General Statistics Office of Vietnam, a body of the Vietnamese Government. The article also uses enterprises' information from Vietnam Report, a company specialising in evaluating and ranking businesses in Vietnam.

This article collected empirical data in Quang Ninh province during 2020 through two projects on livelihoods and coastal residents sponsored by the Vietnam Academy of Social Sciences. In these studies, authors collect data from statistics from the Quang Ninh province People's Committee. The research team conducted in-depth interviews and group discussions with local leaders, residents, hoteliers, restaurants, and tourism businesses. The questions focused on livelihood issues and the impact of the COVID-19 pandemic on the people here.

Quang Ninh has been a very developed province in tourism in recent years, with Ha Long Bay being the center of tourist attraction. Quang Ninh also has a national economic zone in the Van Don district. Therefore, Quang Ninh tourism research can be considered a miniature picture of Vietnam's tourism during the COVID-19 season in 2020.

\section{Results and discussions}

\subsection{The evolution of the COVID-19 pandemic in Vietnam: Three major outbreak stages}

In the first period, from January 22 to March 5, 2020, Vietnam announced a nationwide pandemic and decided to tighten borders and restrict entry.

From March 6 to July 22, 2020, Vietnam suspended entry for all foreigners, and at the same time, implemented a 14-day, and 21-day later concentrated quarantine for all entry cases (Prime Minister of Vietnam 2020a, and 2020b). 
In the third phase, from July 23 to December 11, 2020, Vietnam has 35 deaths from the COVID-19 pandemic, mainly in Da Nang city (Tran, 2020). This number of deaths has shocked the entire tourism industry system because people were afraid of infection when entering epidemic areas.

By the end of 2020, Vietnam had 1465 cases, of which 1325 were cured, and 35 died. (Figure 1)

Many outbreaks have concentrated in tourism-developed provinces such as Ho Chi Minh City, Hanoi, Da Nang, Nha Trang, and Quang Ninh. The emergence of cases seriously hurt the tourism industry. However, when Vietnam controlled the situation well, the demand for transportation for people's recreational activities increased very high.

\section{Figure 1}

Number of COVID-19 infections, cures, and deaths in Vietnam in 2020

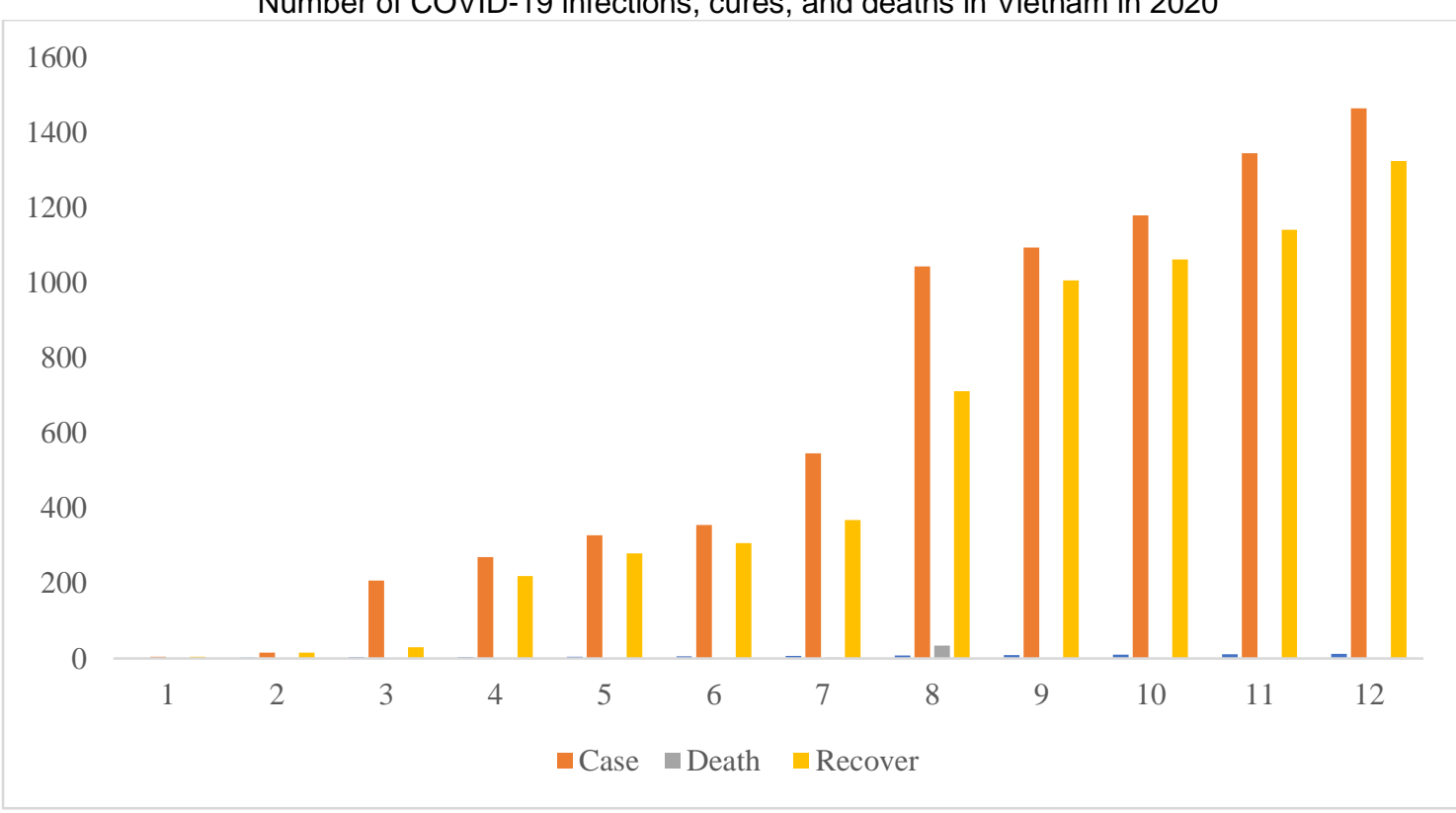

Note: Data compiled by authors from Vietnam Ministry of Health in the website https://ncov.moh.gov.vn/

Based on the events and outbreaks of the Covid-19 outbreaks, the Covid-19 pandemic took place in the peak tourist season of international tourists and tourism seasons of domestic tourists after the Lunar New Year.

By the end of 2020, the tourism industry contributed only US\$13.5 billion, down $41.53 \%$, compared to 2019 (Linh, 2021). Therefore, industrial tourism's contribution to Vietnam's GDP in 2020 is only 2.91\%, compared to $9.2 \%$ in 2019 (VGSO, 2020). In addition, the Covid-19 pandemic resulted in an unemployment rate was about $2.48 \%$, corresponding to 32.1 million working-age people. In the service sector, such as tourism, the unemployment rate was highest, with $71.6 \%$ of workers losing their jobs (VGSO, 2020).

\subsection{Peripheral travellings into Vietnam: From tourists to professionals and humanitarian repatriation}

In the last five years, the number of international visitors to Vietnam has increased from 7.9 million in 2015 to over 18 million in 2019, by 2.2 times (VGSO, 2020). Among the ten countries with the highest number of tourists entering Vietnam, tourists from China and South Korea were the most, with 5.8 and 4.2 million people. In addition, Japan and Taiwan also had nearly 1 million tourists entering Vietnam in 2019 (Figure 2).

However, in 2020, international tourist arrivals were only 3.8 million people, reduced by almost $80 \%$ (Figure 2). In order to maintain the economy and rescue Vietnamese people in countries having outbreaks of the COVID-19 pandemic, the Vietnamese Government implemented a policy of exchanging bilateral flights between countries and repatriating Vietnamese people returning home, including stranded Vietnamese tourists, international students, and people visiting relatives. This 
process also slightly increased the number of international tourists in Vietnam because professionals came to Vietnam to work in international corporations or projects.

Figure 2

Comparing the increase and decrease of international tourists in Vietnam between 2019 and 2020

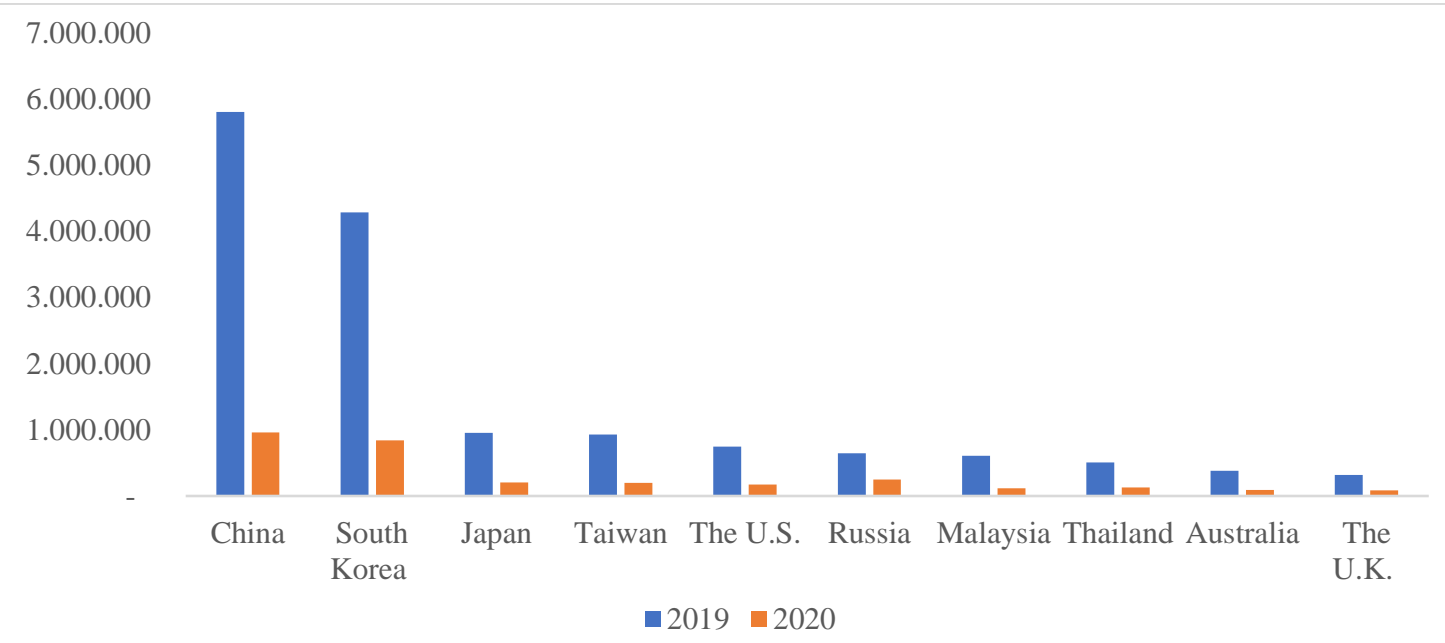

Source: Data compiled by authors from VGSO (2021)

\subsection{Changing the structure of tourism: Upholding the spirit of nationalism}

In 2020, domestic tourists reached 56 million, accounting for nearly $66 \%$ of domestic visitors in 2019. Hotel room occupancy in many localities such as Ha Long city (Quang Ninh province), Sapa town (Lao Cai province), and Phu Quoc Island (Kien Giang province) has reached up to $30-50 \%$, and at weekends, the booking rate up to $80-90 \%$ in the period having no epidemic appearing in the communities (VSGO, 2020).

In Quang Ninh province, the province will reduce $50 \%$ of ticket prices to visit $\mathrm{Ha}$ Long Bay, the museum, and Yen Tu Pagoda's scenic relic site for visitors from September 9 to the end of 2020 tourism demand after the times of the COVID-19 pandemic. In particular, Quang Ninh province offered free admission tickets for guests staying on Ha Long Bay on major holidays such as Vietnamese Women's Day (October 20), Vietnamese Teachers' Day (November 20), and Mining Day of workers (November 12).

Due to the effectiveness of the stimulus process, in September, Quang Ninh province welcomed 120,000 visitors. In the first ten days of October, the number of visitors reached 92,000 . From October $11-15$, the number of visitors doubled compared to the first ten days of October.

As a result, in the first nine months of 2020, the total number of tourists to Quang Ninh has reached over 5.8 million arrivals, equaling $52 \%$ over the same period in 2019, of which international visitors are over 500,000 arrivals, equaling $13 \%$ over the same period last year. 2019. Total tourism revenue reached over US\$521.7 million, equaling 56\% of the same period in 2019. (HL, 2021).

The two most essential policies that promoted industrial tourism by the Vietnamese Government were "Vietnamese people travel to Vietnam" in May 2020 and "Safe and attractive tourism in Vietnam" in September 2020. These two policies uphold the spirit of the Vietnamese people to "beating the pandemic like beating invaders" and only travel within Vietnam to support the Government's socioeconomic development policies (Nong \& Ha, 2021). Furthermore, these policies also provided applications based on a 4.0 technology platform, such as the Vietnam Safe Travel application on iOS or $\mathrm{CH}$ Play operating system. Therefore, travelers and tourism enterprises use this application to check, reflect, and evaluate safe destinations for holidays and recreations. 


\subsection{Survival of sectors in the tourism industry: Profit, loss, and bankruptcy}

Figure 3 shows that most businesses related to the tourism industry experienced a very sharp drop in revenue in 2020. Almost all companies have suffered heavy losses among the state-owned transport enterprises, such as Vietnam Railway and Vietnam Airlines. Vietnam Airlines had a negative profit of US\$478 million, while in the same period, US\$101 million in profit. Vietnam Railway was in danger of going bankrupt entirely due to insufficient revenue and expenses.

Other travel businesses, resorts, hotels, and restaurants also suffered heavy losses, such as Vinpearl (US\$422.3 million), Saigontourist (US\$3.7 million), and Benthanhtourist (US\$1.6 million).

However, some other businesses had profit in 2020, even though their revenue has dropped significantly. For example, FLC and Vietjet's profits reached US\$13.3 million and US\$3 million, respectively (Tu, 2021). However, these enterprises had to sell aircraft, ownership rights, and subsidiary enterprises with no core values in their business ecosystem.

In addition, many businesses, in order to survive, had to change their sales methods by reducing sales prices, reducing employees, or shifting a part to production and services such as producing hand sanitizer and safe masks. For example, hotels and restaurants turned to food and beverage sales through applications on Facebook, Grab Food, Now, or their websites.

By the end of the COVID-19 pandemic year in 2020, Vietnam had 102,000 businesses bankrupt or dissolved, 4,300 travel businesses, and 3,884 hotels and restaurants close (VGSO, 2020). In 2020, the country had 2,519 international travel businesses, but most of them temporarily stopped operating or switched to domestic travel businesses. In addition, 26,721 instructors, with 16,965 also switching to domestic instruction or changing careers. In addition, more than 30,000 accommodation establishments with 650,000 rooms across the country, but the room capacity is only $20-25 \%$ in the provinces and cities; In some key tourist areas, many hotels were forced to close or change their use because they could not stand it.

According to reports from provinces, many provinces reduced $90 \%$ of tourists as usual. For example, Ho Chi Minh City had only 1.3 million international visitors (down $85 \%$ compared to 2019). Khanh Hoa province got 1.2 million visitors (down $82.3 \%$ ), of which international visitors only reached 435,000 arrivals (down $87.8 \%$ ). Da Nang city only had 881,000 international visitors (down 69.2\%), and Quang Ninh had 536,000 international arrivals (down 90.6\%) (Huy, 2021).

A survey in Quang Ninh province shows that the province currently has 500 cruise ships and more than 10,000 workers who have been seriously affected, interrupted, or lost their jobs. In Van Don district, Quang Ninh province, a center for oysters and marine fish, up to 1200 seafood farming households have been affected with 6,000 tons of oysters and 520 tons of fish stagnant, which cannot be sold to tourists or exported to Vietnam. Taiwan and China. Seafood processing enterprises have to sell products at break-even prices or process frozen products until the epidemic is over to deal with the situation.

Many 4- and 5-star hotels register as quarantine points with a fee for people returning from abroad to earn more revenue, subsistence during the ongoing pandemic. For example, in Ho Chi Minh City, there were 41 hotels. Hanoi capital also had 19 hotels, including famous 5 -star hotels such as Hyatt Regency West Hanoi, Hilton Garden Inn, Sofitel Legend Metropole Hanoi, and Wyndham Garden Hanoi, charging US\$2,500-7,200 for 21-days away (Ha \& Thu, 2020). 
Figure 3

Comparing 2019 and 2020 revenue of leading Vietnamese tourism enterprises

\begin{tabular}{|c|c|c|c|}
\hline \multirow[t]{2}{*}{ Enterprises } & \multicolumn{2}{|c|}{$\begin{array}{c}\text { Revenue } \\
\text { (Million US dollars) }\end{array}$} & \multirow[t]{2}{*}{ Sources and Notes } \\
\hline & 2019 & 2020 & \\
\hline Vietravel & 295 & 73 & $\begin{array}{l}\text { - Vietravel, } 2021 . \\
\text { - State enterprise, airline, selling tours, } \\
\text { events, hotels, resorts, and restaurants. }\end{array}$ \\
\hline Saigontourist & 217.3 & 57 & $\begin{array}{l}\text { - Saigontourist, } 2021 . \\
\text { - State enterprise, selling tours, events, } \\
\text { hotels, resorts, and restaurants. }\end{array}$ \\
\hline Benthanhtourist & 42.6 & 15.6 & $\begin{array}{l}\text { - Benthanhtourist, } 2021 . \\
\text { - State enterprise, selling tours, events, } \\
\text { hotels, resorts, and restaurants. }\end{array}$ \\
\hline Hanoitourist & 44.3 & 5.3 & $\begin{array}{l}\text { - Le, } 2020 \text {. Data only for the half-year of } \\
2020 . \\
\text { - State enterprise, selling tours, events, } \\
\text { hotels, resorts, and restaurants. }\end{array}$ \\
\hline Vinpearl & 371,7 & 211,7 & $\begin{array}{l}\text { - Vingroup, } 2021 . \\
\text { - Private enterprise, hotels, resorts, and } \\
\text { restaurants. }\end{array}$ \\
\hline FLC & 595.6 & 443,4 & $\begin{array}{l}\text { - FLC, } 2021 . \\
\text { - Private enterprise, hotels, resorts, and } \\
\text { restaurants. }\end{array}$ \\
\hline Vietnam Airlines & $4,361.50$ & $1,765.70$ & $\begin{array}{l}\text { - Quynh, 2021; Vietnam Airlines (2020). } \\
\text { - State enterprise, airline. }\end{array}$ \\
\hline Vietjet & 2,200 & 791.4 & $\begin{array}{l}\text { - Vietjet, } 2021 . \\
\text { - Private enterprise, airline. }\end{array}$ \\
\hline Vietnam Railway & 356.5 & 285.4 & $\begin{array}{l}\text { - Nam \& Dung, 2020; Tu, } 2021 . \\
\text { - State enterprise, transportation. }\end{array}$ \\
\hline
\end{tabular}

\section{Conclusion}

This study has shown the impacts of the COVID-19 pandemic on the tourism industry in Vietnam in 2020. At the end of the COVID-19 pandemic year, Vietnam's tourism industry has been hurt intensely by reducing revenue to $41.53 \%$ compared to 2019 .

The tourism industry has suffered the most damage in the history of Vietnam's tourism (both international tourism and domestic tourism) due to the Covid-19 pandemic. Almost all tourism businesses have stopped operating, hundreds of the thousands of workers quit. The airline, hotel, travel, and restaurant industries suffered the most due to a sharp decline in international and Chinese tourists to Vietnam.

The transportation industry, in which air transport is heavily influenced by international passengers using Vietnam's air, accounts for nearly $80 \%$. Chinese visitors to Vietnam by air account for $70 \%(2019)$. Road and rail transport services are also negatively affected when trade and tourism activities decline, festival visitors decrease. Transport support services also decreased, such as flight management services and airport services. 
The research shows that many tourism enterprises are on the verge of bankruptcy, reducing the scale of operations or temporarily stopping operations. Tourism enterprises have profit only if they restructure business activities. This study also shows that, while private tourism enterprises have not received much support from the state, state enterprises prioritise the Government's support package. For example, Vietnam Airlines received a US\$174 million loan with 0\% interest (Phung, 2021). This study also shows that Vietnam's tourism structure during the COVID-19 pandemic is the linkages between airlines, travel agencies, restaurants, hotels, and destinations to create safe destinations, ensure the health and safety of domestic tourists, avoid crowded contact, close range, short-term trip.

The economic implications to the COVID-19 pandemics to Vietnam in 2020 is a situation in which GDP has been severely reduced in recent years. The consequence may be that the economy lacks sustainable financial resources for basic construction and implementation of socio-economic development programs, ensuring social security.

This study has certain limitations, especially in terms of time frame only in 2020. The Covid-19 pandemic will clearly have its long-term consequences that the research team has not yet seen. The results of this study are just the beginning of a looming crisis for the tourism industry in Vietnam just one year after the CPVID-19 pandemic.

\section{References}

1. Asia Foundation. (2020). Enduring the pandemic: Rapid survey in the impact of COVID-19 on smes in the tourism sector and households in Cambodia. https://asiafoundation.org/wpcontent/uploads/2021/01/Cambodia_Enduring-the-Pandemic_rapid-survey-on-the-impact-ofcovid-19-on-msmes-in-the-tourism-sector-and-households-in-cambodia_en.pdf

2. Beh, L., \& Lin, W. L. (2021). Impact of COVID-19 on ASEAN tourism industry. Journal of Asian Public Policy. https://doi.org/10.1080/17516234.2020.1871180

3. Benthanhtourist (BenThanh Tourist Service Corporation). (2021). Bao cao thuong nien nam 2020 [Annual report 2020]. https://static2.vietstock.vn/data/HNX/2020/BCTN/VN/BTV_Baocaothuongnien_2020.pdf

4. Cooper, C., Bedard, F., Duguay, B., Hawkins, D., Khomsi, M. R., Mata, J. \& Perdomo, Y. (2019). 'Case studies in sociocultural innovation'. In E. Fayos-Solà \& C. Cooper (Eds.), The future of tourism (pp.111-127). Springer. https://doi.org/10.1007/978-3-319-89941-1_12

5. Dube, K., Nhamo, G. \& Chikodzi, D. (2021). COVID-19 cripples global restaurant and hospitality industry. Current Issues in Tourism, 24(11), 1487-1490. https://doi.org/10.1080/13683500.2020.1773416

6. Foo, L., Chin, M., K., Tan \& Phuah, K. (2020). The impact of COVID-19 on tourism industry in Malaysia. Current Issues in Tourism. https://doi.org/10.1080/13683500.2020.1777951

7. Gopalakrishnan, B. N., Peters, R. \& Vanzetti, D. (2020). COVID-19 and tourism: Assessing the economic consequences. United Nations Conference on Trade and Development report. https://unctad.org/system/files/official-document/ditcinf2020d3_en.pdf.

8. Gössling, S., Scott, D. \& Hall, C. M. (2021). Pandemics, tourism and global change: a rapid assessment of COVID-19. Journal of Sustainable Tourism, 29(1), 1-20.

https://doi.org/10.1080/09669582.2020.1758708

9. Ha, N. \& Thu, K. (2020, December 15). Khach san sang cho khach cach ly, gia phong nhieu lua chon [Luxury hotels waiting for guests to isolate, with many choices in rates]. Vietnmanet online. https://vietnamnet.vn/vn/kinh-doanh/thi-truong/ha-noi-san-sang-don-khach-cach-ly-gia-phongvan-dat-do-674746.html

10.HL. (2021, May 28). Du lich Quang Ninh vuot kho lay lai da tang truong [Quang Ninh tourism overcomes difficulties to regain growth momentum]. Dang cong san online. https://dangcongsan.vn/tu-tuong-van-hoa/du-lich-quang-ninh-vuot-kho-lay-lai-da-tang-truong572123.html, data access 01/05/2021 
11.Huy, G. (2021, May 22). Du lich Viet Nam 2021 tim thoi co trong thach thuc [Vietnam tourism 2021 found opportunities in challenges]. Dang cong san online. https://dangcongsan.vn/chao-xuan-tansuu-2021/dat-nuoc-vao-xuan/du-lich-viet-nam-2021-tim-thoi-co-trong-thach-thuc-574536.html

12.FLC (FLC Group). (2021). Bao cao tai chinh kiem toan hop nhat nam 2020 [Consolidated audited financial statements for 2020]. http://www.flc.vn/co-dong/bao-cao-tai-chinh/

13.Le, N. (2020, May 01). Hanoitourist khang dinh thuong hieu du lich thu do [Hanoitourist affirms the capital's tourism brand]. Kinh te do thi online. http://kinhtedothi.vn/hanoitourist-khang-dinhthuong-hieu-du-lich-thu-do-388075.html

14.Linh, T. (2021, May 21). Du lich Viet Nam 2020: Phat huy noi luc trong "bao COVID-19" [Vietnam tourism 2020: Promoting internal strength in the "COVID-19 storm"]. Nhan dan. https://nhandan.vn/dien-dan-dulich/du-lich-viet-nam-2020-phat-huy-noi-luc-trong-bao-covid-19630469/

15.Nam, V., \& Dung, T. (2020, May 24). Nam 2019, nganh duong sat dat doanh thu gan 8.200 ty dong [In 2019, the railway industry achieved nearly 8,200 billion VND]. Thoi bao tai chinh online. http://thoibaotaichinhvietnam.vn/pages/kinh-doanh/2020-01-04/nam-2019-nganh-duong-satdat-doanh-thu-gan-8200-ty-dong-81127.aspx

16.Nong, N. B. \& Ha, V. H. T. (2021). Impact of Covid-19 on Airbnb: Evidence from Vietnam. Journal of Sustainable Finance \& Investment. https://doi.org/10.1080/20430795.2021.1894544

17.Prime Minister of Vietnam. (2020a). Chi thi so 15/CT-TTg ve quyet liet thuc hien dot cao diem phong, chong dich COVID-19 ngay 27 thang 3 nam 2020 [Directive No.15/CT-TTg on drastically implementing the peak of the COVID-19 pandemic prevention and control, dated March 27 2020]. Hanoi.

18.Prime Minister o Vietnam. (2020b). Chi thi so 16 ve viec thuc hien cac bien phap cap bach phong, chong dich COVID-19 ngay 31 thang 3 nam 2020 [Directive No. 16/CT-TTg on the implementation of urgent measures to prevent and control the COVID-19 pandemic dated March 31 2020]. Hanoi.

19.Phung, T. (2021, April 20). Vietnam Airlines duoc tiep can khoan vay 4.000 ti dong, lai suat $0 \%$ [Vietnam Airlines accessed to a loan of 4,000 billion Vietnam Dong with $0 \%$ interest]. Tuoi tre online. https://tuoitre.vn/vietnam-airlines-duoc-tiep-can-khoan-vay-4-000-ti-dong-lai-suat-020210108165709911.htm

20.Quynh, L. (2021, May 01). Vietnam Airlines bao lo rong gan 11.098 ty dong trong nam 2020 [Vietnam Airlines reported a net loss of nearly 11,098 billion Vietnam Dong in 2020]. Tin nhanh chung khoan online. https://tinnhanhchungkhoan.vn/vietnam-airlines-hvn-bao-lo-rong-gan-11098-ty-dong-trong-nam-2020-post261343.html

21.Saigontourist. (2021). Bao cao tai chinh 2020 [Finalcial report in 2020]. https://www.saigontourist.net/vi/chi-tiet/597/bao-cao-tai-chinh-2020

22.Tran, D. P. (2020). Chung song an toan voi dich COVID-19 trong dieu kien binh thuong moi [Safe coexistence with the COVID-19 pandemic under new normal conditions]. In The gioi va Viet Nam trong dai dich COVID-19. Nationa Conference of the Vietnam Academy of Social Sciences, Hanoi, Vietnam (pp.1-8). Vietnam.

23.Tu, A. (2021, May 03). Duong sat truoc nguy co mat sach 3.200 ty dong von chu so huu do Covid [Railways in danger of losing 3,200 billion VND due to the COVID-19 pandemic]. Tap chi VnEconomy online. https://vneconomy.vn/duong-sat-truoc-nguy-co-mat-sach-3200-ty-dong-von-chu-so-huudo-covid.htm

24.Tu, D. (2021, May 05). Hau kiem toan 2020, lai sau thue FLC tang gan 70\% [Post-audit 2020, FLC profit after tax increased by nearly $70 \%$ ]. Tap chi Vietstock. https://vietstock.vn/2021/03/hau-kiemtoan-2020-lai-sau-thue-flc-tang-gan-70-737-833594.htm

25.Vietjet (VietJet Aviation Joint Stock Company). (2021). Bao cao tai chinh hop nhat Quy 4 nam 2020 [Consolidated financial statements for the 4th quarter of 2020].

https://ir.vietjetair.com/File_Upload/thong-tin-tai-chinh/bao-cao-tai-chinh-hangquy/2021/Vietjet\%20BCTC\%20H\%E1\%BB\%A3p\%20nh\%E1\%BA\%A5t\%20Q4.2020.pdf

26.Vietnam Airlines. (2020). Bao cao thuong nien 2019 [Annual Report 2019]. 
https://www.vietnamairlines.com/ /media/FilesDownload/AboutUs/Investor-Relations/Bao-CaoThuong-Nien/new-bao-cao-thuong-nien-2019.pdf

27.VGSO (Vietnam General Statistics Office). (2020). Bao cao tinh hinh kinh te-xa hoi Quy IV va nam 2019 [Report on socio-economic situations of the fourth quarter and 2019.] Hanoi.

28.VGSO. (2021). Nien giam thong ke Viet Nam 2021 [Vietnam statistical yearbook 2021]. Hanoi.

29.Vietnam National Administration of Tourism. (2020, May 22). Toc do tang truong khach cao, dong gop quan trong vao phat trien kinh te-xa hoi [High visitor growth rate, making an important contribution to socio-economic development]. Du lịch Viet Nam.

https://vietnamtourism.gov.vn/index.php/items/32527.

30.Vietralvel. (2021). Bao cao tai chinh 2020 [Financial report 2020]. http://download.vietravel.com.vn/TTTT/B\%C3\%A10\%20c\%C3\%A10\%20t\%C3\%A0i\%20ch\%C3\%AD nh\%20t\%E1\%BB\%95ng\%20h\%E1\%BB\%A3p\%20n\%C4\%83m\%202020\%20(ki\%E1\%BB\%83m\%20to\% C3\%A1n).pdf

31.Vinpearl (2021). Bao cao thuong nien 2020 [Annual report 2020]. https://vinpearl.com/vi/cong-bothong-tin-bao-cao-thuong-nien-2020

32.Vingroup. (2021). Bao cao thuong nien 2020 [Annual report 2020]. https://ircdn.vingroup.net/storage/Uploads/0_Bao\%20cao\%20thuong\%20nien/2020/Vingroup\%2 0-\%20Annual\%20Report\%202020_VN_Final.pdf

33.Yucel, A. G. (2020). Are shocks to tourist arrivals permanent or transitory? A comprehensive analysis on the top 20 most-visited countries. Current Issues in Tourism.

https://doi.org/10.1080/13683500.2020.1828311 